\title{
Efficiency of Organic Nitrogen Fertilization of Potato in Northeast Portugal
}

\author{
A. Rodrigues \\ Crop Production Department \\ Escola Superior Agrária de Bragança \\ Ap. 172 \\ 5301 - 854 Bragança \\ Portugal
}

\author{
J. Coutinho and F. Martins \\ Soil Science Department \\ Universidade Trás-os-Montes e Alto Douro \\ Ap. 202 \\ 5001 - 911 Vila Real \\ Portugal
}

Keywords: farmyard manure, municipal solid waste, poultry manure, nitrogen mineralization, nitrogen uptake, Solanum tuberosum L.

\begin{abstract}
The study was conducted over a 4 year period with the purpose of measuring $\mathbf{N}$ mineralization using an in situ incubation technique, following the application of farmyard manure, poultry manure or municipal solid waste. The results varied from $-10 \%$ (net immobilization) to $+28 \%$ (net mineralization) in relation to the total organic $\mathbf{N}$ applied. $\mathrm{N}$ fluxes were assessed through plant $\mathrm{N}$ analysis during the growing season and through determination of potato tuber dry weight (TDW), $N$ uptake by tubers and the apparent $N$ recovery (ANR) of added $N$ at harvest. Organic material applications slightly increased TDW above the control treatment (9 to $25 \%$ ), although the results indicate a shortage of $\mathrm{N}$, where no $\mathrm{N}$ was added to the crop. The effect of organic fertilization on $\mathbf{N}$ uptake by tubers was also limited. Petiole nitrate concentration and estimated net $\mathbf{N}$ mineralization were in agreement with trends in TDW and $\mathrm{N}$ uptake by tubers, with no differences in soil $\mathrm{N}$ availability between the control and organic treatments. Values of ANR were particularly low, ranging from 4 to $23 \%$. The results suggest that caution is needed when judging the contribution of organic fertilization to $\mathbf{N}$ nutrition of crops, which have a short growing season. Synchronization between $\mathbf{N}$ release and plant uptake is discussed.
\end{abstract}

\section{INTRODUCTION}

Farmyard manures have been utilized for centuries to maintain or increase the fertility of cropped soils. Nowadays, many conventional farms are interested in their use, particularly for vegetable production. At the same time there is an incentive for the application of organic materials to crops due to (i) increased availability of processed and marketed off-farm residues, (ii) increased environmental concern, promoting the utilization of organic waste rather than its disposal in landfills, and (iii) the development and effort put into organic farming.

The interest in organic fertilizers and amendments is due to their organic matter and nutrient content. The effect of organic matter is mainly due to the improvement of the physical (Schjønning et al., 1994; Benbi et al., 1998) and electrochemical (MacCarthy et al., 1990) properties of soils, often related to soil remediation and soil reclamation. In relation to nutrient supply, application of organic residues may reduce the amount of mineral fertilization required, and so consequently information is needed to quantify nutrient availability from organic sources (Brady and Weil, 1996), since environmental and economic pressure on agriculture has prompted farmers to make more efficient use of nutrients.

Nitrogen management practices and its fate in soil are particularly important since this nutrient is associated with environmental problems, including pollution of ground and surface waters (Magdoff et al., 1997). $\mathrm{N}$ mineralization-immobilization turnover (MIT) depends on the chemical composition, $\mathrm{C} / \mathrm{N}$ ratio and decomposability indices of the organic materials added to the soil (Vigil and Kissel, 1991; Janssen, 1996). Net mineralization increases $\mathrm{N}$ availability to plants and, therefore, should increase yield and 
reduce the need for chemical fertilizer for optimal crop production. On the contrary, $\mathrm{N}$ immobilization temporarily limits the availability of mineral forms and reduces the efficiency of the inorganic fertilizer (Braakhekke et al., 1993). Aside from the overall balance of MIT, the synchronization between $\mathrm{N}$ supply from organic sources and crop demand is crucial for the efficient use of the applied N. Thus, organic inputs must be well timed to contribute to an efficient use of N (Mengel, 1996).

Although incubations and chemical methods have been tested, a reliable laboratory method to assess the rate and pattern of $\mathrm{N}$ mineralization is not available (Douglas and Magdoff, 1991) due to the complexity of the mineralization processes (Jarvis et al., 1996). Consequently, the rates of $\mathrm{N}$ mineralization from organic sources are not well known and uncertainties occur when calculating $\mathrm{N}$ application, leading to the possibility of underfertilization or excessive nitrate leaching. A field experiment was carried using three organic materials as sources of $\mathrm{N}$ for potato, and field measurements of $\mathrm{N}$ mineralization were made using an in situ incubation technique. Yield, $\mathrm{N}$ nutritional status during the growing season, $\mathrm{N}$ uptake and apparent $\mathrm{N}$ recovery were measured during the growing season. The organic materials were traditional cattle farmyard manure, off-farm manure from poultry and non-agriculture residue from municipal solid wastes.

\section{MATERIAL AND METHODS}

The field experiments were conducted over a four year period (1995-1998) at Bragança, Northeast Portugal. Five treatments consisting of cattle farmyard manure (FYM), fresh poultry manure (PM), municipal solid waste compost (MSW), urea and a control (non- $\mathrm{N}$ fertilization), organized in a block design with three replicates, were set up on a loamy eutric Fluvisol, with an organic matter content of about $15 \mathrm{~g} \mathrm{~kg}^{-1}$. Urea and organic materials were applied at a rate equivalent to $100 \mathrm{~kg} \mathrm{~N} \mathrm{ha}^{-1}$ and incorporated to a depth of $14 \mathrm{~cm}$ at planting time (Tables 1 and 2). Potato (Solanum tuberosum L. cv. Désirée) was used as test crop since it is considered to be particularly responsive to manures (Holliday et al., 1965). The crop was irrigated and was integrated into a 4-yr rotation (3-yr. maize, 1-yr. potato), using Triticosecale spp. as catch crop during the winters. Colorado potato beetle (Leptinotarsa decemlineata) and blight (Phytophthora infestans) were controlled using integrated pest management.

A sequential in situ coring technique was used to measure $\mathrm{N}$ mineralization during the growing season. The procedure was similar to that used by Hatch et al. (1990), but without the addition of acetylene as nitrification inhibitor. Six soil cores were taken with PVC tubes (14 cm high, $32 \mathrm{~mm}$ id) and placed in closed $1 \mathrm{~L}$ glass jars in $0.15 \mathrm{~m}$ deep holes in the ground adjacent to the experimental plots and incubated for periods of about 14 days. The sum of the fortnightly changes in inorganic $\mathrm{N}$ during the growing season, about 112 days, was used to estimate net $\mathrm{N}$ mineralization. Soil mineral nitrogen (SMN) was determined in non-incubated and incubated fresh samples with $\mathrm{KCl} 2 M$ (ratio 1:5). The concentration of $\mathrm{N}-\mathrm{NH}_{4}{ }^{+}$was analyzed by Berthelot reaction and $\mathrm{N}_{-} \mathrm{NO}_{3}{ }^{-}$by the Griess-Ilosvay reagent after reduction in a Cd column (Houba et al., 1989), both by molecular absorption spectroscopy in a segmented flow analysis system.

At harvest, relative yield was calculated based on tuber dry weight (TDW) of the commercial class $(\varnothing>35 \mathrm{~mm}) . \mathrm{N}$ nutritional status of the plants during the growing season was evaluated by the nitrate concentration at 15-20 days after emergence (DAE) in the petioles of the youngest fully-expanded leaf (Mills and Jones, 1996). At harvest, total $\mathrm{N}$ tuber concentration was determined by wet digestion according to Novozamsky et al. (1983). The apparent $\mathrm{N}$ recovery (ANR) was calculated by the difference method (Tyler et al., 1983), taking into account the control and each organic or urea treatment.

\section{RESULTS AND DISCUSSION}

The $\mathrm{N}$ mineralized over 112 days is presented in Table 3. Over the four years, $\mathrm{N}$ mineralization in the control treatment was fairly constant, with an average mineralization rate of $0.71 \mathrm{~kg} \mathrm{~N} \mathrm{ha}^{-1} \mathrm{day}^{-1}$ at a depth of $0.14 \mathrm{~m}$, showing a steady release of $\mathrm{N}$ from soil 
organic matter as a result of homogeneity of soil characteristics and previous crop effects among fields and years. The amounts of $\mathrm{N}$ mineralized in the soil after the addition of PM were significantly higher than those observed for the control, except for 1995. Application of FYM and MSW resulted in similar N release values in each of these two treatments, which did not differ from the control treatment.

The results show minimum values of $-10 \%$ (net immobilization) for MSW in 1996 and maximum of $28 \%$ (net mineralization) for PM in 1997 and 1998, in relation to the total $\mathrm{N}$ applied in organic forms. The composition of organic residues was widely variable (Table 2) and $\mathrm{N}$ mineralization was generally related to the $\mathrm{C}: \mathrm{N}$ ratio of the organic materials, as referred by Whitmore and Groot (1994), and to its mineral N concentration, which may strongly modify the MIT balance (Mary et al., 1996), which was in agreement with the observations of Chadwick et al. (1997) and Coutinho et al. (1998).

The modest effect of manuring on the amount of $\mathrm{N}$ released is also reflected in SMN availability to the crop during the growing season, as shown for 1997 in Figure 1, with similar results in the other 3 years. Amongst the organic treatments, significant differences, compared to the control occur only up to $35 \mathrm{DAP}$, and even so only the plots which received PM showed the capacity to maintain higher values than the control. As expected, $\mathrm{N}$ availability with urea treatment was much higher during this period and its sharp drop can be explained by microbial immobilization, plant uptake and leaching, since heavy precipitation $(50-90 \mathrm{~mm})$ occurred after planting. At 49 DAP no differences in SMN were observed among the five treatments. Average residual soil mineral $\mathrm{N}$ after harvest in all treatments was about $6 \mathrm{mg} \mathrm{kg}^{-1}$.

The concentration of $\mathrm{NO}_{3}^{-}$in the petioles was significantly higher using urea than for the control treatment (Table 3). Nitrate is considered to be a sensitive parameter for the evaluation of the $\mathrm{N}$ status of the plant during the growing season (Loon et al., 1987), and related to final yield (Rodrigues et al., 1998). Throughout the 4 year period, the application of urea led to significant increases in TDW relative to the control treatment (Figure 2). Therefore, both parameters clearly indicate a shortage of $\mathrm{N}$, where the supply relies on the release of $\mathrm{N}$ from soil organic matter, and where no additional $\mathrm{N}$ is added.

In spite of this apparent $\mathrm{N}$ shortage of $\mathrm{N}$, added organic materials gave only a slightly increased TDW compared to the control (Figure 2), this is in agreement with the in situ mineralization results. Differences were significant only for FYM in 1995, and PM in 1996 and 1997. On average, PM application gave the highest yield: $87 \%$ of relative TDW, against 81,78 and $71 \%$ for FYM, MSW and control respectively, although there was high variability between years. Limited yield response to FYM was also reported by Goffart et al. (1997), this was explained by the C:N ratio of the FYM and the consequent lack of $\mathrm{N}$ mineralization. However, no adverse effect of MSW on yield was noticed when compared with FYM.

Among organic treatments, $\mathrm{NO}_{3}{ }^{-}$concentration in the petioles was higher for PM, except in 1995. Application of FYM and MSW resulted in similar values, which did not differ from the control treatment (Table 3), this same pattern was also observed for accumulated $\mathrm{N}$ mineralization (Table 3) and SMN (Figure 1). $\mathrm{N}$ uptake by tubers (Figure 3) also showed the same trend, although the differences amongst treatments appear to be greater than those observed for TDW. Low yields were related to lower tuber $\mathrm{N}$ concentration, probably as a consequence of the $\mathrm{N}$ deficit. As a consequence of low $\mathrm{N}$ release, low efficiency of the organic materials in $\mathrm{N}$ nutrition, low nitrogen uptake and low yields, the values of ANR for the organic $\mathrm{N}$ are also low (Table 4).

During the 4 year period, FYM, PM and MSW showed average ANR values of 4, 23 and $6 \%$ respectively. These values are particularly poor; potato however, is considered to be an inefficient crop in using and translocating $\mathrm{N}$ (Joern and Vitosh, 1995a,b), which may explain the average value of $49 \%$ for urea in this low input system of $100 \mathrm{~kg} \mathrm{~N} \mathrm{ha}{ }^{-1}$. Other studies have also shown a low efficiency in similar organic fertilizers with corn (Schröder and Dilz, 1987; Grignani and Acutis, 1994) vegetable crops (Brito and Hadley, 1993), and potato (Rodrigues and Coutinho, 1996). 
$\mathrm{N}$ requirement for potatoes appears to be critical early in the season (Westterman and Kleinkopf, 1985) and this may explain why some organic treatments, which released their $\mathrm{N}$ more quickly, had the ability to increase yield. In this experiment the application of exclusively organic materials was unable to supply the potatoes demand for $\mathrm{N}$. The same may also be true for similar vegetable crops, which do not produce high yields in soils with a low or medium SMN baseline. Moreover, continuing $\mathrm{N}$ mineralization after the end of growing season, in addition to any crop residues, may increase the risk of losses by leaching and denitrification if no following crop is grown and no other control is practiced.

\section{CONCLUSIONS}

The modest effect of manuring on yield is confirmed by the low $\mathrm{NO}_{3}{ }^{-}$ concentration in the petioles, and this is in agreement with the differences in the amounts of $\mathrm{N}$ mineralized and available as SMN from the different organic sources.

The variability in the composition of the organic fertilizers and amendments, and their consequent effect on SMN makes it particularly important to develop quick and reliable tests for estimating the behavior of manures under field conditions, so that they may be used to benefit agriculture.

\section{ACKNOWLEDGEMENTS}

This work was partially supported by research projects PAMAF 6107 and PRAXIS XXI P/Agr/11045/98. Therefore, authors wish to thank the Ministry of Agriculture and the Foundation for Science and Technology. The authors are also grateful to David Underwood for its helpful advice in the English version of the manuscript.

\section{Literature Cited}

Benbi, D.K., Biswas, C.R., Bawa, S.S. and Kumar, K. 1998. Influence of farmyard manure, inorganic fertilizers and weed control practices on some soil physical properties in a long-term experiment. Soil Use and Management 14:52-54.

Braakhekke, W.G., Stuurman, H.A., van Reuler, H. and Janssen, B.H. 1993. Relations between nitrogen and phosphorus immobilization during decomposition of forest litter. In Optimization of Plant Nutrition, pp 117-123. Eds. Fragoso, M.A.C. and van Beusichem, M.L.. Kluwer Academic Pub. Amsterdam, The Netherlands.

Brady, N.C. and Weil, R.R. 1996. The Nature and Properties of Soils. 11th ed. PrenticeHall Inc., N. Jersey, USA.

Brito, L.M. and Hadley, P. 1993. Effects of composted municipal waste and a paper mill waste composted with bark on the growth of vegetable crops. In Optimization of Plant Nutrition, pp 101-106. Eds. Fragoso, M.A.C. and van Beusichem, M.L.. Kluwer Academic Pub. Amsterdam, The Netherlands.

Chadwick, D., John, F., Pain, P., Chambers, B. and Williams, J. 1997. Mineralization of organic nitrogen from animal manures. In Fertilization for Sustainable Plant Production and Soil Fertility, pp. 29-35, vol. II. Eds. Van Cleemput, O., Haneklaus, S., Hofman, G., Schnug, E., and Vermoesen, A. Int. Scientific Centre Fertilizers, Braunschweig, Germany.

Coutinho, J., Matos, J. and Jorge, D. 1998. Patterns of nitrogen mineralization from organic amendments under aerobic incubation with soil. In Proc. $5^{\text {th }}$ Congress European Society Agronomy, pp 45-46., vol II. Colmar, France.

Douglas, B.F. and Magdoff, F.R. 1991. An evaluation of nitrogen indices for organic residues. J. Environ. Qual. 20:368-372.

Goffart, J.P., Rouxhet, F. and Guiot, J. 1997. Influence of organic manures, catch crops and fallow on soil mineral nitrogen production and subsequent potato crop. In Fertilization for Sustainable Plant Production and Soil Fertility, pp. 669-678, vol. I. Eds. Van Cleemput, O., Haneklaus, S., Hofman, G., Schnug, E., and Vermoesen, A. Int. Scientific Centre Fertilizers, Braunschweig, Germany.

Grignani, C. and Acutis, M. 1994. Organic fertilization efficiency and nitrogen leaching 
in maize based forage systems. In Proc. $3^{\text {th }}$ Congress European Society Agronomy, pp 804-805. Colmar, France.

Hatch, D.J., Jarvis, S.C. and Phillips, L. 1990. Field measurements of nitrogen mineralization using soil core incubation and acetylene inhibition of nitrification. Plant and Soil, 124:97-107.

Holliday, R., Harris, P.M. and Baba, M.R. 1965. Investigations into the mode of action of farmyard manure. I. The influence of soil moisture conditions on the response of maincrop potatoes to farmyard manure. J. Agric. Sci. (Camb.) 64:161-166.

Houba, V. J., van der Lee, J.J., Novozamsky, I. and Walinga, I. 1989. Soil and Plant Analysis. Part 5 - Soil Analysis Procedures. Wageningen Agricultural University, Wageningen, The Netherlands.

Janssen, B.H. 1996. Nitrogen mineralization in relation to C:N ratio and decomposability of organic materials. Plant Soil, 181:47-56.

Jarvis, S.C., Stockdale, E.A., Shepherd, M.A. and Powlson, D.S. 1996. Nitrogen mineralization in temperate agricultural soils: processes and measurement. Adv. Agronomy 57:187-235.

Joern, B.C. and Vitosh, M.L. 1995a. Influence of applied nitrogen on potato. Part I: yield, quality, and nitrogen uptake. Am. Potato J. 72:51-63.

Joern, B.C. and Vitosh, M.L. 1995b. Influence of applied nitrogen on potato. Part II: recovery and partitioning of applied nitrogen. Am. Potato J. 72:73-84.

Loon, C.D. van., Slangen, J.H.G. and Houwing, J.H. 1987. Nitrate content of leaf petioles as a guide to optimalization of $\mathrm{N}$-fertilization of ware potatoes. In: Proc. 10 th Triennial Conference of EAPR, pp. 146-147. Aalborg, Denmark.

MacCarthy, P., Bloom, P.R., Clapp, C.E. and Malcolm, R.L. 1990. Humic substances in soil and crop sciences: an overview. In Humic Substances in Soil and Crop Sciences, pp 261-271. Eds. MacCarthy, P., Clapp, C.E., Malcolm, R.L., and Bloom P.R. A.S.A., S.S.S:A., Madison, Wisconsin, USA.

Magdoff, F., Lanyon, L. and Liebhardt, B. 1997. Nutrient cycling, transformations, and flows: implications for a more sustainable agriculture. Adv. Agronomy 60:1-73.

Mary, B., Recous, S., Darwis, D. and Robin, D. 1996. Interactions between decomposition of plant residues and nitrogen cycling in soil. Plant Soil 181:71-82.

Mengel, K. 1996. Turnover of organic nitrogen in soils and its availability to crops. Plant Soil 181:83-93.

Mills, H.A. and Jones Jr., J.B. 1996. Plant Analysis Handbook. MicroMacro Pub. Inc., Athens, Georgia, USA.

Novozamsky, I., Houba, V.J.G., van Eck, R. and van Vark, W. 1983. A novel digestion technique for multi-element plant analysis. Commun. Soil Sci. Plant Anal. 14:239249.

Rodrigues, M.A., Coutinho, J. and Martins, F. 1998. Metodologias expeditas para maximizar a eficiência da fertilização azotada. In VII Colóquio Nacional de Produção de Batata, pp 37-50. Associação Portuguesa de Horticultura, Lisboa, Portugal.

Rodrigues, M.A.R. and Coutinho, J. 1996. Efficiency of uptake and utilization of $\mathrm{N}$ from mineral and organic sources by potato crop. In Proc. $4^{\text {th }}$ Congress European Society Agronomy, pp 368-369. Colmar, France.

Schjønning, P., Christensen, B.T. and Carstensen, B. 1994. Physical and chemical properties of a sandy loam receiving animal manure, mineral fertilizer or no fertilizer for 90 years. Eur. J. Soil Sci. 45:257-268.

Schröder, J. and Dilz, K. 1987. Cattle slurry and farmyard manure as fertilizers for forage maize. In Animal Manure on Grassland and Fodder Crops. Fertilizer or Waste? pp 137-156. Eds. van der Meer, H.G., Unwin, R.J., van Dijk, T.A., and Ennik, G.C. Martinus Nijhoff Pub. Dordrecht, The Netherlands.

Tyler, K.B., Broadbent, F.E. and Bishop, J.C. 1983. Efficiency of nitrogen uptake by potatoes. Am. Potato J. 60:261 - 269.

Vigil, M.F. and Kissel, D.E. 1991. Equations for estimating the amount of nitrogen mineralized from crop residues. Soil Sci. Soc. Am. J. 55:757-761. 
Westerman, D.T. and Kleinkopf, G.E. 1985. Nitrogen requirements of potatoes. Agronomy J. 77:616-621.

Whitmore, A.P. and Groot, J.J.R. 1994. The mineralization of $\mathrm{N}$ from finely or coarsely chopped crop residues: measurements and modelling. European J. Agronomy 3:367373.

\section{Tables}

Table 1. Manuring and crop planting and harvest dates during the experimental period

\begin{tabular}{llllll}
\hline year & manuring & potato planting & potato harvest & tritic. planting & tritic. harvest \\
\hline 1995 & 4 Jun & 5 Jun & 10 Oct & 19 Oct & 22 Apr (96) \\
1996 & 27 May & 28 May & 18 Sep & 20 Oct & 24 Apr (97) \\
1997 & 27 May & 28 May & 24 Sep & 23 Jan & 23 Apr (98) \\
1998 & 20 May & 21 May & 28 Sep & 21 Oct & 28 Apr (99) \\
\hline
\end{tabular}

Table 2. Some characteristics of the organic materials under study

\begin{tabular}{|c|c|c|c|c|c|c|c|c|c|c|c|c|}
\hline & \multicolumn{4}{|c|}{$\mathrm{N}$ kjeldhal $\left(\mathrm{g} \mathrm{kg}^{-1}\right)$} & \multicolumn{4}{|c|}{$\mathrm{C}: \mathrm{N}$ ratio } & \multicolumn{4}{|c|}{ mineral $\mathrm{N}\left(\mathrm{mg} \mathrm{kg}^{-1}\right)$} \\
\hline & 1995 & 1996 & 1997 & 1998 & 1995 & 1996 & 1997 & 1998 & 1995 & 1996 & 1997 & 1998 \\
\hline FYM & 27 & 12 & 17 & 19 & 10.7 & 11.6 & 10.0 & 11.3 & 634 & 323 & 566 & 310 \\
\hline PM & 17 & 40 & 35 & 30 & 7.9 & 4.7 & 7.0 & 6.5 & 855 & 1436 & 2320 & 1118 \\
\hline MSW & 15 & 17 & 22 & 14 & 14.9 & 14.7 & 11.5 & 12.1 & 395 & 237 & 718 & 183 \\
\hline
\end{tabular}

Table 3. Accumulated $\mathrm{N}$ mineralization during the growing season and effect of urea and organic material application on petiole $\mathrm{NO}_{3}{ }^{-}$concentration at 15-20 DAE

\begin{tabular}{|c|c|c|c|c|c|c|c|c|}
\hline & \multicolumn{4}{|c|}{ accumulated $\mathrm{N}$ in soil $\left(\mathrm{mg} \mathrm{kg}^{-1}\right)$} & \multicolumn{4}{|c|}{ petiole $\mathrm{NO}_{3}^{-}\left(\mathrm{g} \mathrm{kg}^{-1} \mathrm{DM}\right)$} \\
\hline & 1995 & 1996 & 1997 & 1998 & 1995 & 1996 & 1997 & 1998 \\
\hline control & $55.2^{\mathrm{a}^{\mathrm{*}}}$ & $64.2^{b}$ & $41.5^{b}$ & $50.8^{\mathrm{b}}$ & $65^{b^{*}}$ & $65^{\mathrm{c}}$ & $32^{\mathrm{c}}$ & $63^{\mathrm{bc}}$ \\
\hline urea & - & - & - & - & $113^{\mathrm{a}}$ & $118^{\mathrm{a}}$ & $122^{\mathrm{a}}$ & $101^{\mathrm{a}}$ \\
\hline FYM & $53.7^{\mathrm{a}}$ & $63.7^{\mathrm{b}}$ & $45.1^{\mathrm{ab}}$ & $50.7^{\mathrm{b}}$ & $76^{\mathrm{b}}$ & $77^{\mathrm{c}}$ & $20^{\mathrm{c}}$ & $55^{\mathrm{c}}$ \\
\hline PM & $51.4^{\mathrm{a}}$ & $75.8^{\mathrm{a}}$ & $59.5^{\mathrm{a}}$ & $69.6^{\mathrm{a}}$ & $70^{\mathrm{b}}$ & $97^{\mathrm{b}}$ & $53^{b}$ & $76^{b}$ \\
\hline MSW & $55.2^{\mathrm{a}}$ & $57.6^{\mathrm{b}}$ & $54.7^{\mathrm{ab}}$ & $60.6^{\mathrm{ab}}$ & $78^{\mathrm{b}}$ & $68^{\mathrm{c}}$ & $23^{\mathrm{c}}$ & $45^{\mathrm{c}}$ \\
\hline
\end{tabular}

*within each year, mean values with the same letter do not differ significantly $(\mathrm{P}<0.05)$ by Fisher's LSD test 
Table 4. Values of apparent nitrogen recovery (\%) for the urea and the organic materials applied to the potato crop

\begin{tabular}{lllll}
\hline & 1995 & 1996 & 1997 & 1998 \\
\hline urea & 39.5 & 57.9 & 59.0 & 40.7 \\
FYM & 10.3 & 1.7 & -6.1 & 10.7 \\
PM & 6.4 & 32.1 & 32.6 & 20.3 \\
MSW & 11.2 & -0.4 & 6.8 & 5.9 \\
\hline
\end{tabular}

\section{Figures}

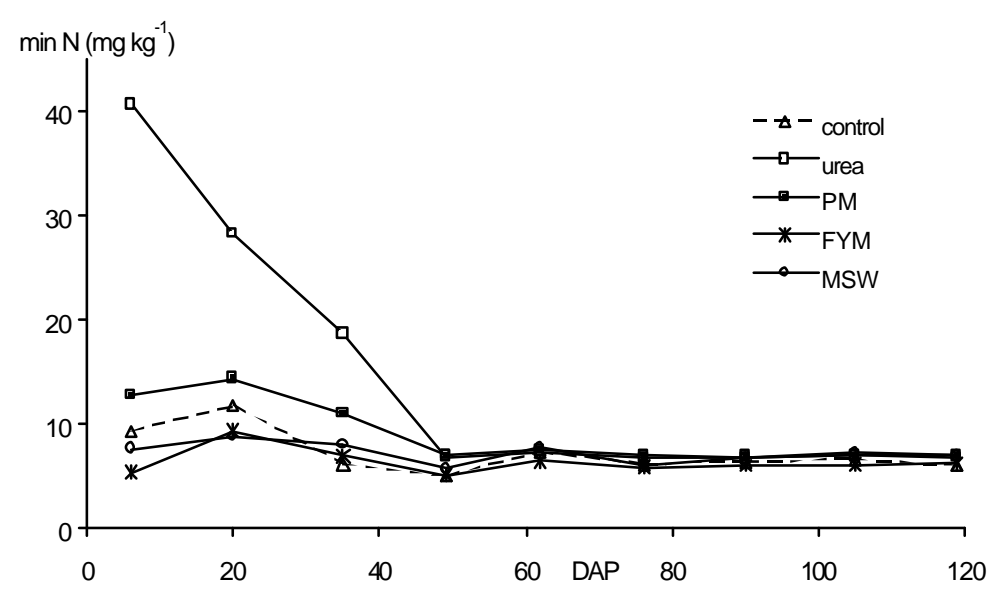

Fig. 1. Soil mineral $\mathrm{N}$ concentration $(0-14 \mathrm{~cm})$ during the growing season -1997 $\left(\mathrm{LSD}_{0.05}=1.9\right)$ 


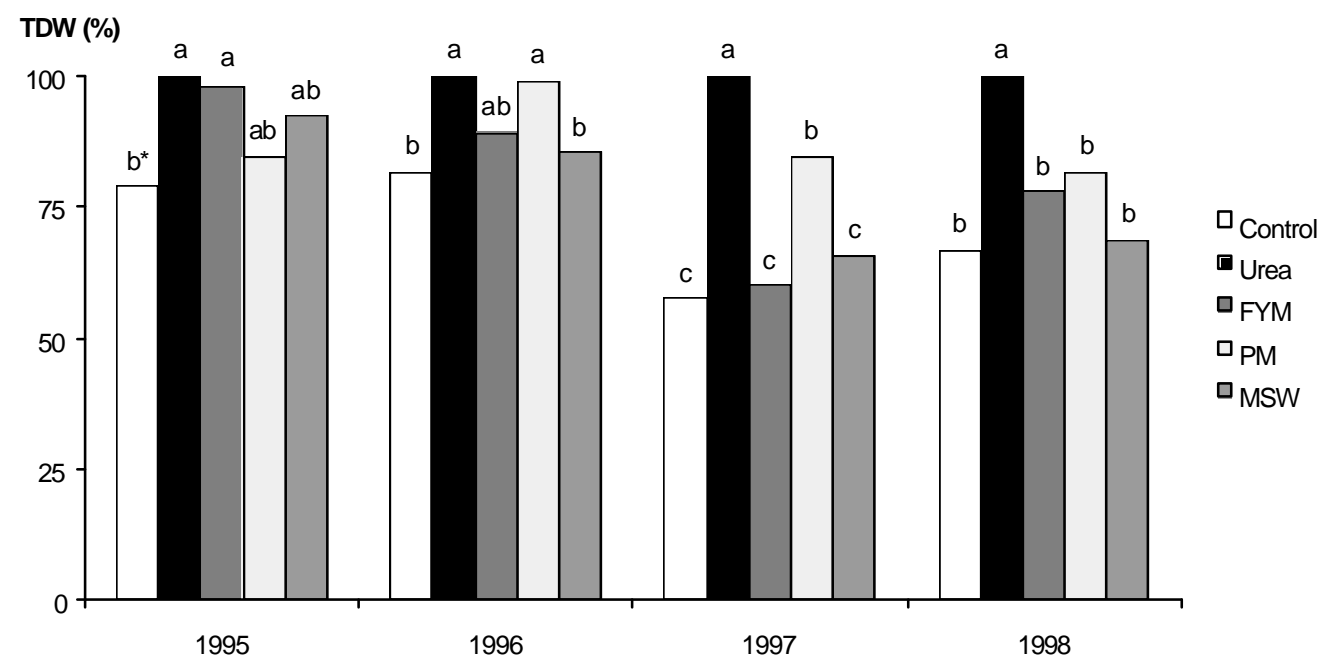

*within each year, mean values with the same letter do not differ significantly $(\mathrm{P}<0.05)$ by Fisher's LSD test

Fig. 2. Effect of urea and organic material application on relative tuber dry weight $\left(\%\right.$ TDW). Maximum yield = 24.7 (1995), 48.8 (1996), 42.1 (1997) and $45.1 \mathrm{t} \mathrm{ha}^{-1}$ (1998)

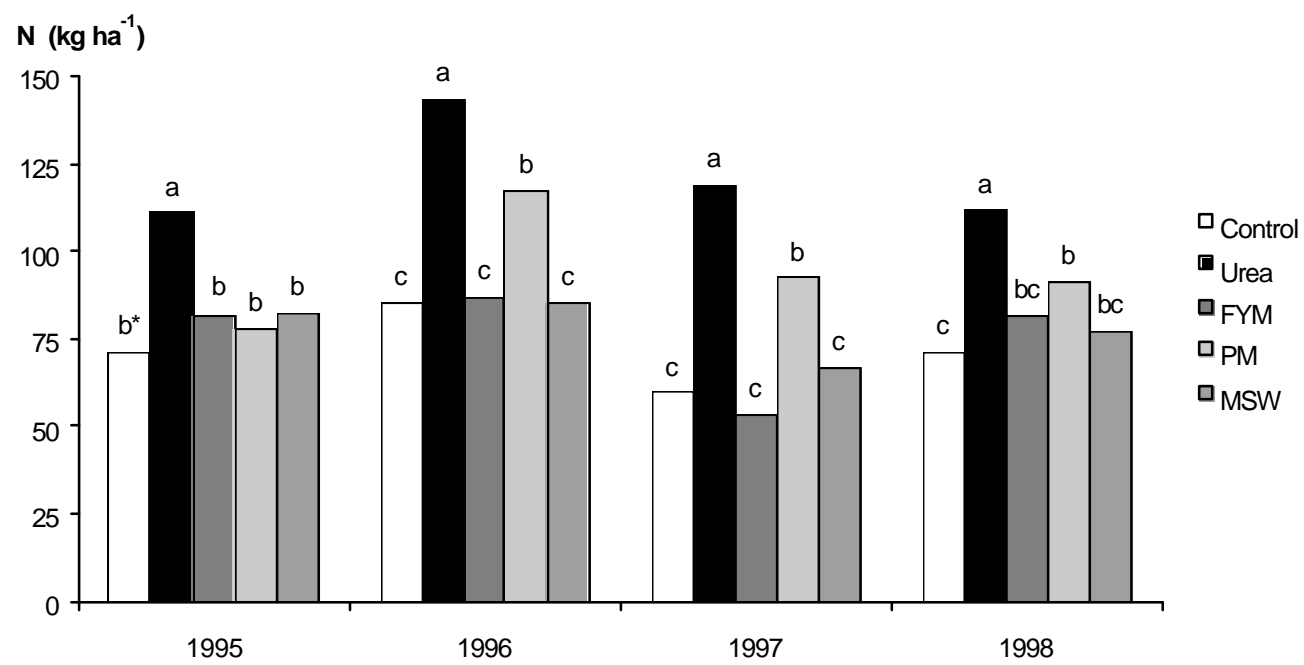

*within each year, mean values with the same letter do not differ significantly $(\mathrm{P}<0.05)$ by Fisher's LSD test

Fig. 3. Effect of urea and organic material application on $\mathrm{N}$ uptake by tubers 